\title{
Biosorption of hexavalent chromium using tamarind (Tamarindus indica) fruit shell-a comparative study
}

\author{
Srinivasa Rao Popuri \\ Environmental Restoration and Disaster Reduction Research Center \\ National Chung Hsing University \\ Taichung, 402, Taiwan \\ Tel: 886972282524 \\ E-mail: popurishrinu@gmail.com
}

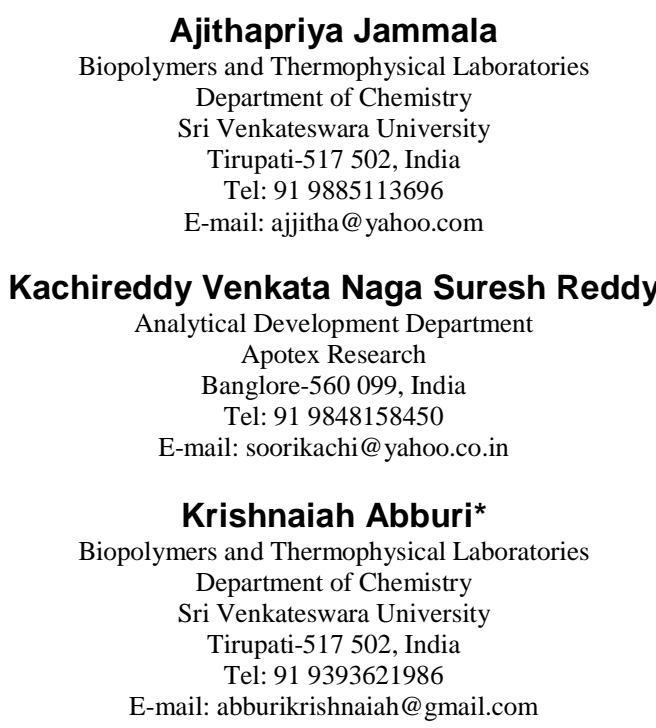

Keywords: biosorption, chromium (VI), pre-treatment, Tamarindus indica fruit shell.

\footnotetext{
Abbreviations: CTFS: crude tamarind fruit shells

H-TS: $\mathrm{HCl}$ treated shells

O-TS: oxalic acid treated shells
}

The adsorption of chromium (VI) ions from aqueous solutions has been investigated on crude tamarind fruit shell, HCl treated and Oxalic acid treated shells at room temperatures. The biosorbents are characterized by FTIR, EDXRF and porosimetry. The biosorption experiments are conducted through batch system. The influence of different experimental parameters such as pH, effect of initial metal ion concentration and effect of dosage of adsorbent on biosorption are evaluated. The adsorption followed first order kinetics. The data are fitted well to Langmuir and Freundlich isotherm models. A comparison is drawn on the extent of biosorption between untreated and treated forms of the tamarind shells. Due to their outstanding adsorption capacities, tamarind shells are excellent sorbents for the removal of chromium ions.
Increased knowledge about toxicological effects of heavy metals on the environment is well recognized and therefore, it is inevitable to search for different methods to reduce water pollution (Mahvi et al. 2005). The major sources of heavy metal contaminations are the industrial effluents. Due to their persistence in nature, it becomes essential to remove them from wastewaters (Klimmrk et al. 2001). Conventional techniques have limitations (Ozdemir et al. 2004) and often are neither effective nor economical especially for the removal of heavy metals at low concentrations. New separation methods are effective and environmentally acceptable at affordable cost (Volesky, 1994).

An alternative method for the removal of heavy metals is considered based on the biological methods of metal

*Corresponding author 
removal and recovery. The ability of microorganisms to remove heavy metals from aqueous solutions has been known for some decades (Volesky, 1990). The removal of the metals occur actively only with living cells and/or passively at the surface of dead cells. This is known as biosorption. Biosorption is a fast and reversible reaction of the heavy metals with microorganisms or biomass. The byproducts obtained from biomaterial production are a cheap source of biosorbents. Therefore biosorption is potentially cost effective way of removing heavy metals from industrial wastewaters. The process is effective even if the concentration is as low as $200 \mu \mathrm{g} / \mathrm{ml}$. Several approaches have been studied and developed for the effective removal of heavy metals using biosorbents like peat (Brown et al. 2000; Ricou-Hoeffer et al. 2001), fly ash (Ho and Mckay, 2000), microbial biomass (Texier et al. 1999) and other agricultural by products (Laszlo and Dintzis, 1994), soya bean hulls (Marshall et al. 2000) walnut hulls (Wartelle and Marshall, 2000), cotton seed hulls and corn cobs (Reddad et al. 2002). It has also been observed that these biosorbents need further modifications to increase the active binding sites and also made them readily available for sorption. Huang and Huang (1996) stated that pre-treatment of biomass removes the surface impurities on the biosorbents and expose the available binding sites for metal sorption (Cabuk et al. 2005).

The aim of the present study is to investigate the biosorption of chromium (VI) on crude tamarind fruit shells (CTFS), $\mathrm{HCl}$ treated shells (H-TS) and oxalic acid treated shells (O-TS) and compare their performance. In the present work, adsorbents are prepared from tamarind shells and treated with acids and utilized for the removal of hexavalent chromium from synthetic solutions. The effect of time, initial concentration of the metal, solution $\mathrm{pH}$ and adsorbent dosage on the biosorption at room temperature are also studied and compared. The kinetic data is checked for the pseudo first order reaction and the rate constants are evaluated. The equilibrium data are fitted with Langmuir and Freundlich isotherms equations. Further the biosorbents are characterized by FT-IR, to examine the metal accumulation due to the presence of different functional groups on biosorbent, EDXRF for elemental analysis and porosity.

\section{MATERIALS AND METHODS}

\section{Biosorbent}

Tamarind fruit shells, a waste product of tamarind pulp, are used for the removal of $\mathrm{Cr}$ (VI) ions from aqueous solutions. These shells are collected from tamarind fruit pods in Tirupati town, A.P., India, and are powdered and sieved to get uniform size (60-80) mesh particle size. They are washed thoroughly with distilled water and dried in the oven for $2 \mathrm{hrs}$ at $60^{\circ} \mathrm{C}$. It is used as a biosorbent (CTFS).

\section{Pre-treatment of the biosorbent}

The pre-treatment of tamarind shells is carried out to increase the metal uptake efficiency. $10 \mathrm{~g}$ of the tamarind shells are treated with $100 \mathrm{ml} 1 \mathrm{~N} \mathrm{HCl}$ and $1 \mathrm{~N}$ Oxalic acid for $24 \mathrm{hrs}$ separately and kept on the water bath $\left(70^{\circ} \mathrm{C}\right)$ for half an hr. It is cooled and is neutralized with $50 \mathrm{ml}$ of $1 \mathrm{~N}$ $\mathrm{NaOH}$. The filtrates are separated and are dried in the oven for $4 \mathrm{hrs}$ at $60^{\circ} \mathrm{C}$. Thus the pretreated tamarind fruit shells $\mathrm{H}-\mathrm{TS}$, and O-TS are used as a second and third biosorbent.

Table 1. Conversion of $\mathrm{Cr}(\mathrm{VI})$ to $\mathrm{Cr}(\mathrm{III})$ at different $\mathrm{pH}$.

\begin{tabular}{|c|c|}
\hline $\mathbf{p H}$ & Reduction of $\mathbf{C r}(\mathbf{V I})$ to $\mathbf{C r}(\mathbf{I I I}) \mathbf{( m g} / \mathbf{L})$ \\
\hline 1 & 6.183 \\
\hline 2 & 3.039 \\
\hline 3 & 1.013 \\
\hline 4 & 0.021 \\
\hline 5 & 0.000 \\
\hline 6 & 0.000 \\
\hline
\end{tabular}

\section{Effect of $\mathrm{pH}$}

The effect of $\mathrm{pH}$ on chromium biosorption on CTFS, H-TS, O-TS are studied at room temperature by varying $\mathrm{pH}$ of chromium solution. The $\mathrm{pH}$ of the solutions is adjusted with $0.05 \mathrm{~N} \mathrm{HCl}$ and $0.05 \mathrm{~N} \mathrm{NaOH}$ by making use of digital $\mathrm{pH}$ meter (Hanna Instruments, Italy).

\section{Batch studies}

An adsorbate stock solution of $1000 \mathrm{mg} / \mathrm{l}$ of $\mathrm{Cr}(\mathrm{VI})$ is prepared by dissolving $2.829 \mathrm{~g}$ of potassium dichromate in double distilled water. Batch adsorption experiments are carried out by shaking $100 \mathrm{mg}$ of biosorbent mixed with $100 \mathrm{ml}$ of potassium dichromate solution of known concentration in $200 \mathrm{ml}$ Erlenmeyer bottles at room temperature in a rotatory mechanical shaker at $80 \mathrm{rpm}$. The effect of contact time, metal ion concentration, $\mathrm{pH}$ are studied. The bottles are removed after the desired contact time and the filtrates are analyzed using atomic adsorption spectrophotometer (Perkin Elmer 280) and UV-Visible spectrophotometer (Elico-180). All chemicals used are of analytical grade obtained from Glaxo, India, Ltd. Double distilled water is used in preparing the stock solutions and also throughout the experimental analysis.

Four samples of chromium ion concentrations varying from $50-200 \mathrm{mg} / \mathrm{L}$ were treated with $100 \mathrm{mg}$ of the biosorbent. In acidic media some part of chromium (VI) was reduced to the trivalent state when it contacts with organic substance. $\mathrm{Cr}$ (III) was oxidized to $\mathrm{Cr}(\mathrm{VI})$ by potassium permanganate and sodium azide and analyzed by spectrophotometrically (Systronics-118) at wavelength $540 \mathrm{~nm}$ using diphenyl carbozide as complexing agent (Prakasham et al. 1999). 


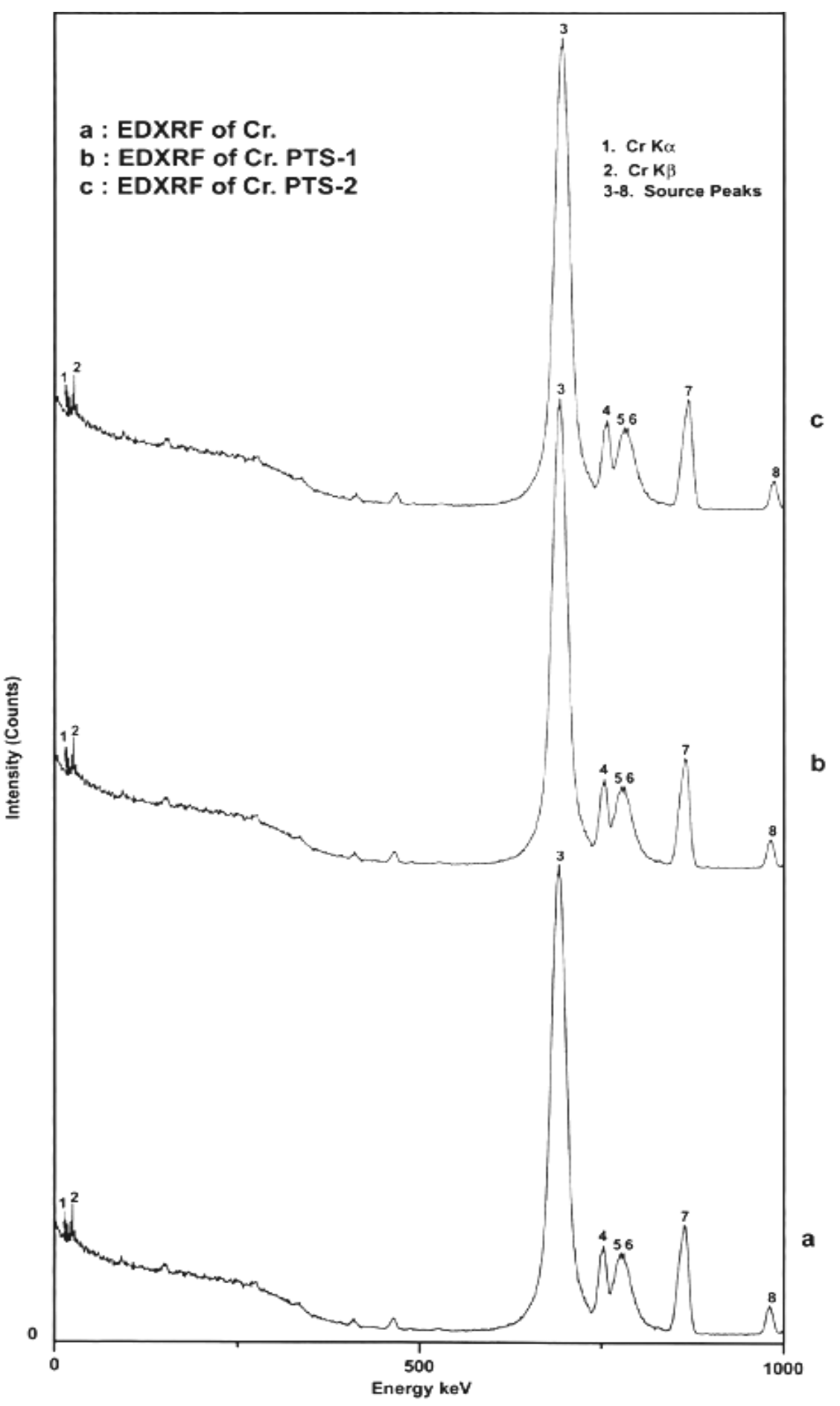

Figure 1. EDXRF spectra of tamarind shell.

With increasing $\mathrm{pH}$, reduction of chromium from hexavalent state to trivalent state is also decreases. In the present work, the optimum $\mathrm{pH}$ for chromium adsorption was found to be 3.0 and at this $\mathrm{pH}$ reduction of chromium (VI) to chromium (III) was less. Detailed description of the paper. The data of the reduction of chromium from hexavalent state to trivalent was depicted in Table 1. Total unadsorbed chromium (VI) was calculated by taking the difference of initial concentration and total hexavalent chromium concentration in the filtrate. 


$$
\mathrm{Cr}(\mathrm{VI}) \text { adsorbed }=\left(\begin{array}{c}
\text { Initial chromium } \\
\text { concentration }
\end{array}\right)-\left(\begin{array}{c}
\text { chromium concentration in the filtrate } \\
+ \text { chromium reduced from VI to III }
\end{array}\right)
$$

After the equilibrium is attained by each system, the metal uptake capacity for each sample is calculated according to mass balance on the metal ion using

$$
q_{e}=\left(\frac{\mathrm{C}_{i}-\mathrm{C}_{e}}{m}\right) \cdot v
$$

where $C i$ and $C e$ are initial and equilibrium concentrations of $\mathrm{Cr}(\mathrm{VI})$ respectively, $\mathrm{m}$ is the mass of adsorbent and $V$ is volume of solution in litres.

\section{Characterization}

The biosorbents are characterized using pycnomatic ATC (microstructures) -It is designed for the analysis of solids and extremely fine powders. The real density of the solid is calculated from the ratio of the dried sample weight and the volume is measured by the pycnomatic. From these values of pore volume, specific volume is calculated from which percent porosity of each sample is obtained.

Energy dispersive X-ray fluorescence spectrophotometer is an instrument used to determine the presence of an element both qualitatively and quantitatively. The solid pieces, loose powders and granules are directly paced on to the XRF instrument and analyzed with a single calibration. Thermo Electron Corporation, EDXRF spectra analysis (ED 2000 model), used in the detection of chromium is designed specifically for heavy metal analysis in environmental samples.

Infrared spectroscopy detects the vibrations of chemical function groups in a given sample. A Fourier transform infrared spectrometer, (Nicolet IR-200 spectrometer), used in this analysis gives the information of the spectra of the compounds being analyzed. The spectra collected are within the range $4000-450 \mathrm{~cm}^{-1}$ using a $\mathrm{KBr}$ window. The background obtained from the scan of pure KBR is automatically subtracted from the sample spectra. The spectra plotted are having the same scale on the transmittance axis.

\section{RESULTS AND DISCUSSION}

\section{Characterization of biosorbents}

Pycnomatic ATC. Porosity is defined as the fraction of pore volume $\mathrm{Vp}$ of the adsorbent that is attributed to the pores detected (Rouquerol et al. 1994)

$$
\dot{\varepsilon}=\mathrm{Vp} / \mathrm{V}
$$

where $\dot{\varepsilon}$ is porosity, $\mathrm{Vp}=$ pore volume and $\mathrm{V}=$ apparent volume.
Porosity is one of the factors that influence the chemical reactivity of solids and physical interaction of solids with liquids and gases. Percent porosity is measured by taking one gram of the biosorbent and these values are presented in Table 2. Pretreated biosorbents showed increased pore volume, decreased density and high percentage of porosity indicating more pores are available for adsorption of metal ions after the pretreatment.

Table 2. Porosity values of biosorbents.

\begin{tabular}{|c|c|c|c|}
\hline Biosorbent & Pore volume (cc) & Density (g/cc) & \% Porosity \\
\hline CFTS & 0.2053 & 4.869 & 30.85 \\
\hline H-TS & 0.2232 & 4.480 & 33.70 \\
\hline O-TS & 0.2466 & 4.055 & 37.4 \\
\hline
\end{tabular}

EDXRF studies. An EDXRF analysis is a surface sensitive technique used to measure almost every element from $\mathrm{Na}$ to $\mathrm{Pu}$ in the periodic table. X-rays observed in fluorescent analyses typically have energies ranging from $1-100 \mathrm{KeV}$. These photons can only penetrate a few millimeters into substance so that it reflects the composition of the substance not the core or overall composition. Elemental analysis of biosorbents after biosorption is studied from the spectra of EDXRF and is shown in Figure 1. From the spectral data the three biosorbents show the presence of chromium at $5.4(\mathrm{~K} \alpha)$ and $5.98 \mathrm{KeV}(\mathrm{K} \beta)$. The penetration of photons into the substance reflects the composition of the substance and this is seen from the peaks obtained at respective energies for chromium.

FTIR spectral studies. FT-IR spectra given in Figure 2 shows peaks at $3550-3400 \mathrm{~cm}^{-1}$ indicating the presence of $\mathrm{OH}$ or $-\mathrm{NH}$ groups. In Figure $2 \mathrm{a}$, the presence of peaks at 1750-1730 $\mathrm{cm}^{-1}$ correspond to $\mathrm{C}=\mathrm{O}$ stretching i.e. aromatic ester groups in the crude form and these peaks do not appear in the pretreated forms (Figure 2b, Figure $2 \mathrm{~d}$ and Figure 2e). The peaks present at $800-700 \mathrm{~cm}^{-1}$ indicate the presence of aromatic orthodisubstituted heterocyclic molecules, but these peaks are also absent in the metal adsorbed spectra of chromium. This indicates that there is a possibility of ring cleavage after the biosorption of chromium. Thus the binding capacities of the pretreated forms are higher than the crude form. From the spectral data it is concluded that in the pretreated forms the ester groups are already converted into acid groups by the pretreatment and decarboxylation occurs after the adsorption of chromium. Peak at $2600 \mathrm{~cm}^{-1}$ (Figure 1c) indicates the presence of $\mathrm{O}-\mathrm{H}$ group obtained from conversion of ester into acid. It may be stated that the rate of hydrolysis and the rate of adsorption also influence the adsorption capacity of the biosorbent. Therefore, the adsorptive capacities of the pretreated biosorbents are greater than the crude form. Treatment of biomass with $\mathrm{HCl}$ implies the protonation which displaces the light metal ions from the binding sites (i.e., carboxylic, sulfonic, and others). According to Huang 


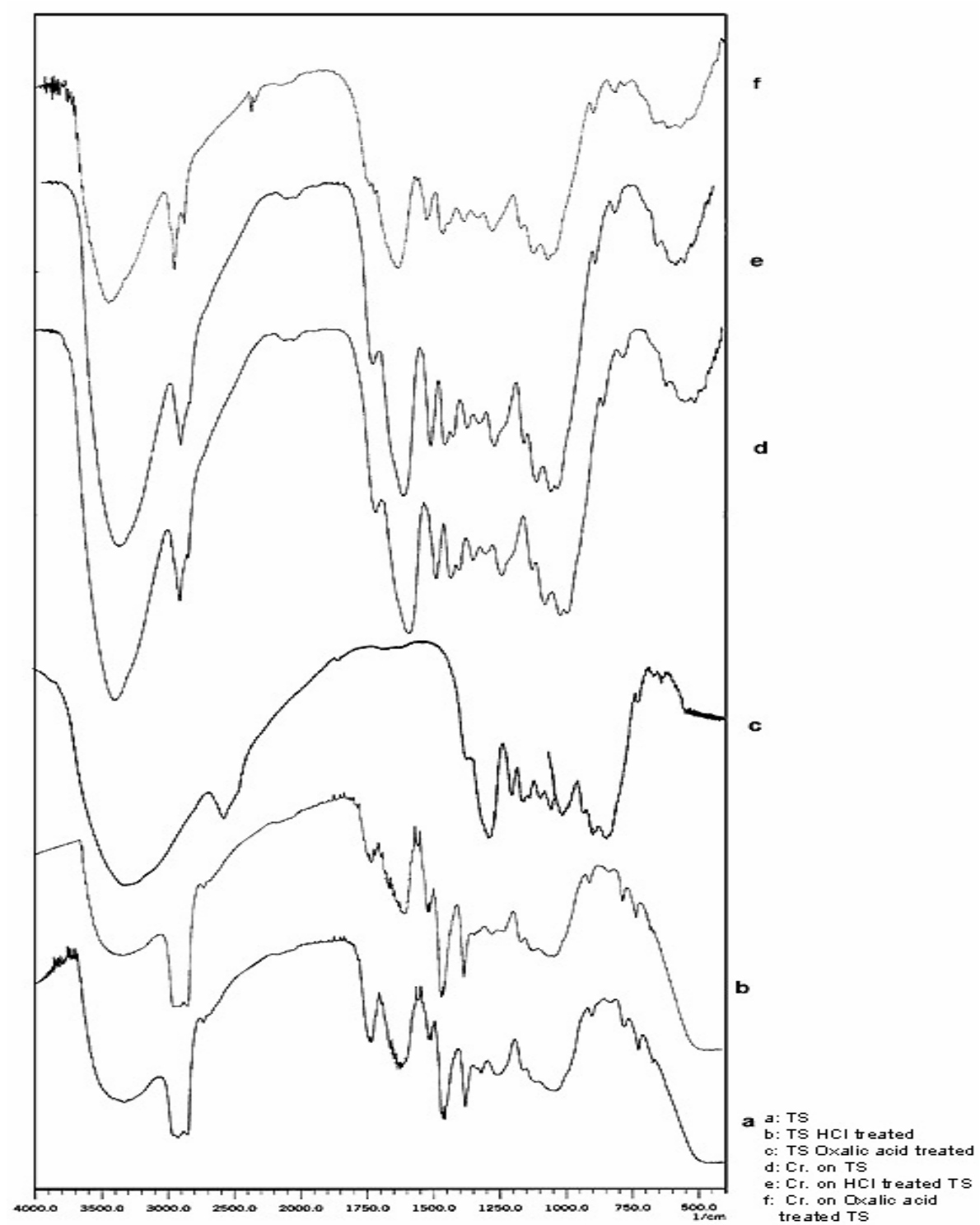

Figure 2. FTIR spectra of tamarind shell.

and Huang (1996), acid treated biomass contained a higher percentage of surface nitrogen. This indicates that acid treatment may dissolve polysaccharide compounds in the outer layer of the cell wall and therefore produce additional binding sites. Acid treatment results not only in a clean-up of the surface impurities, stabilization of the surface compounds, and increases the surface area by opening the available sites for metal adsorption.

Table 3. $\mathrm{K}_{\mathrm{ad}}$ values of the biosorbents for the adsorption of $\mathrm{Cr}(\mathrm{VI})$.

\begin{tabular}{|c|c|c|c|}
\hline Concentration (mg/L) & CFTS & H-TS & O-TS \\
\hline 50 & 0.014 & 0.031 & 0.037 \\
\hline 100 & 0.014 & 0.031 & 0.037 \\
\hline 150 & 0.014 & 0.031 & 0.036 \\
\hline 200 & 0.014 & 0.031 & 0.037 \\
\hline
\end{tabular}

\section{Effect of $\mathrm{pH}$}

Since the solution $\mathrm{pH}$ can significantly influence the removal of heavy metals, it is therefore an important condition for adsorption of $\mathrm{Cr}(\mathrm{VI})$ ions. Experiments over a range of $\mathrm{pH}$ values (1-8) with $100 \mathrm{mg} / \mathrm{L}$ of chromium solution in Figure 3 reveal that biosorption capacity of chromium is maximum at $\mathrm{pH}$ 3. Agarwal et al. (2006) reported similar results in the biosorption of chromium (VI) by tamarind shell. Tamarind shells are a rich source of protein and amino acids (Marathe et al. 2002). Some functional groups, such as amines, are positively charged when protonated and may electrostatically bind with negatively charged metal complexes. At lower $\mathrm{pH}$, the biosorbent is positively charged due to protonation and dichromate ion exists as anion leading to an electrostatic attraction between them (Boddu et al. 2003). As $\mathrm{pH}$ is increases, deprotonation starts and there by results 
indecrease of adsorption capacity. Chromium (VI) forms stable complexes such as $\mathrm{Cr}_{2} \mathrm{O}_{7}^{-2}, \mathrm{HCrO}_{4}{ }^{-1}, \mathrm{CrO}_{4}{ }^{-2}$, and $\mathrm{HCr}_{2} \mathrm{O}_{7}^{-1}$ depending on the $\mathrm{pH}$ of the solution. The fraction of any particular species depends upon the chromium concentration and $\mathrm{pH}$ of the solution (Udaybhaskar et al. 1990; Kawamura et al. 1997). Speciation studies of Cr(VI) in aqueous solution, on the basis of spectrophotometry, electrochemistry, freezing point depression and NMR, indicates the existence of the following equilibria;

$$
\begin{gathered}
\mathrm{H}_{2} \mathrm{CrO}_{4}=\mathrm{H}^{+}+\mathrm{HCrO}_{4^{-}} \\
\mathrm{HCrO}_{4}^{-1}=\mathrm{H}^{+}+\mathrm{CrO}_{4}{ }^{2-} \\
2 \mathrm{HCrO}_{4}^{-1}=\mathrm{Cr}_{2} \mathrm{O}_{7}^{-2}+\mathrm{H}_{2} \mathrm{O}
\end{gathered}
$$

Equilibria are dependent on $\mathrm{pH}$, with $\mathrm{HCrO}_{4}{ }^{-1}$ and $\mathrm{Cr}_{2} \mathrm{O}_{7}{ }^{-2}$ existing primarily in acidic media and $\mathrm{CrO}_{4}{ }^{2-}$ being the lone species of $\mathrm{Cr}(\mathrm{VI})$ above $\mathrm{pH}$ 7.0. At higher $\mathrm{pH}$ range, the fraction of $\mathrm{Cr}_{2} \mathrm{O}_{7}^{-2}$ species rapidly decreases with increasing $\mathrm{pH}$ above 5. The chromium adsorption and $\mathrm{pH}$ curves imply that the $\mathrm{Cr}_{2} \mathrm{O}_{7}^{-2}$ ion is the principal ion being adsorbed on the tamarind fruit shell.

Table 4. Langmuir and Freundlich constants for the biosorption of $\mathrm{Cr}(\mathrm{VI})$ on biosorbents.

\begin{tabular}{|c|c|c|c|c|c|c|}
\hline \multirow{2}{*}{ Biosorbent } & \multicolumn{3}{|c|}{ Langmuir } & \multicolumn{3}{c|}{ Freundlich } \\
\cline { 2 - 7 } & $\mathbf{Q}^{\circ}$ & $\mathbf{b}$ & $\mathbf{r}^{\mathbf{2}}$ & $\mathbf{K}_{\mathbf{F}}$ & $\mathbf{n}$ & $\mathbf{r}^{\mathbf{2}}$ \\
\hline CFTS & 74.62 & 0.005 & 0.99 & 3.00 & 0.90 & 0.98 \\
\hline H-TS & 140.84 & 0.007 & 0.99 & 3.06 & 0.70 & 0.98 \\
\hline O-TS & 151.51 & 0.035 & 0.99 & 4.87 & 0.80 & 0.98 \\
\hline
\end{tabular}

The decrease in the adsorption with increase of $\mathrm{pH}$ may be due to the decrease in electrostatic force of attraction between the sorbent and sorbate ions. At lower $\mathrm{pH}$ ranges, due to the high electrostatic force of attraction, the percentage of $\mathrm{Cr}(\mathrm{VI})$ removal is high. At very low $\mathrm{pH}$ value, the surface of sorbent would also be surrounded by the hydronium ions which enhance the $\mathrm{Cr}(\mathrm{VI})$ interaction with binding sites of the biosorbents by greater attractive forces. A sharp decrease in adsorption above $\mathrm{pH} 4$ may be due to occupation of the adsorption sites by anionic species like $\mathrm{HCrO}^{-4}, \mathrm{Cr}_{2} \mathrm{O}_{2}^{-7}, \mathrm{CrO}_{2}^{-4}$, etc., which retards the approach of such ions further toward the sorbent surface (Dönmez and Aksu, 2002). The decrease in adsorption at high $\mathrm{pH}$ values may be due to the competitiveness of the oxyanion of chromium and $\mathrm{OH}^{-}$ions in the bulk. These results suggest that $\mathrm{pH}$ affects the solubility of metals and the ionization state of the functional groups like carboxylate, phosphate and amino groups of the cell walls of the biosorbent.

\section{Effect of contact time and initial concentration of chromium ions}

The equilibrium time required for the biosorption of $\mathrm{Cr}(\mathrm{VI})$ on CTFS, H-TS, O-TS is studied at various initial concentrations $(50-200 \mathrm{mg} / \mathrm{L})$ and with $0.1 \mathrm{~g}$ of the biosorbent at different time intervals.

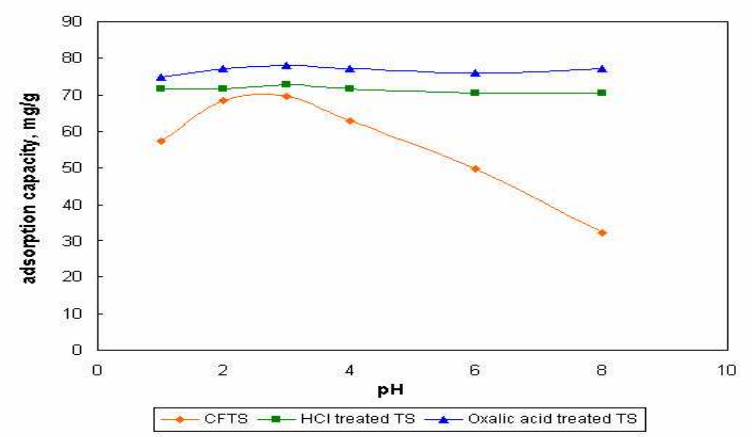

Figure 3. Effect of pH on adsorption.

Figure 4, Figure 5 and Figure 6 show that adsorption capacity sharply increases with increase in time and attains equilibrium in $120 \mathrm{~min}$ for (CFTS), $60 \mathrm{~min}$ for (H-TS), less than $50 \mathrm{~min}$ for (O-TS) respectively. The metal adsorption increased rapidly during the first $20 \mathrm{~min}$ and remained nearly the same afterwards. The rate of adsorption is higher in the beginning due to large available surface area of the biosorbent. After the capacity of the adsorbent gets exhausted, i.e. at equilibrium, the rate of uptake is controlled by the rate at which the adsorbate is transported from the exterior to the interior sites of the biosorbent particles (Verma et al. 2006). The contact time is a very important consideration for the treatment of wastewater and accordingly, the contact time is fixed at a little more than the respective equilibrium times for each of the biosorbent.

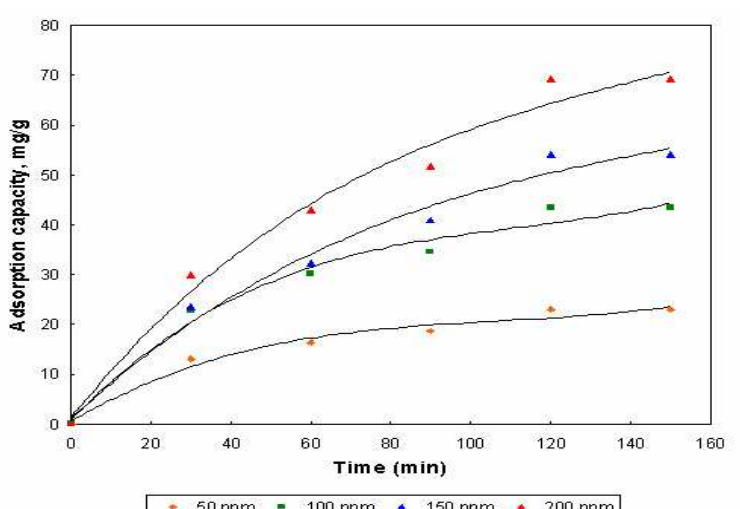

Figure 4. Effect of contact time on adsorption CTFS.

\section{Adsorption kinetics}

Although a range of models is available to study kinetics, Lagergren pseudo first order kinetic model is used for the biosorption of chromium. It should be emphasized that the nature of the metal-ion-sorbent interactions is likely to be different for different biosorbents so that biosorption of metal ions on a particular biosorbent could be a reaction kinetic controlled process, a diffusion controlled process or even a combination of the two (Cheung et al. 2003). The 
rate constant of $\mathrm{Cr}(\mathrm{VI})$ adsorption on CTFS, H-TS and OTS followed the first order rate expression given by Lagergren,

$$
\log \left(q_{e}-q_{t}\right)=\log q_{e}-\left(\frac{K_{a d}}{2.303}\right) t
$$

where $q_{e}$ and $q_{t}$ are amount of metal ion adsorbed per unit mass of adsorbent at equilibrium and at time $t(\min ) . K_{a d}$ is the rate constant of adsorption. The linear plots of $\log \left(q_{e^{-}}\right.$ $q_{t}$ ) versus $t$ for the metal ion studied at different concentrations indicate the approachability of the equation (Shekinaah et al. 2002). Ho and McKay (1999) obtained a similar equation, assuming that the rate limiting step of the reaction may be chemical sorption involving valence forces through sharing or exchange of electrons between the sorbent and the sorbate. From equation 3 the $K_{a d}$ values are calculated and are presented in Table 3 . The values of $K_{a d}$ remains constant irrespective of initial concentration of $\mathrm{Cr}(\mathrm{VI})$ indicates that the adsorption process follows first order kinetics. Further, increase in $K_{a d}$ values for acidtreated biosorbents relative to untreated form reveal that the rate of adsorption process increases upon treatment.

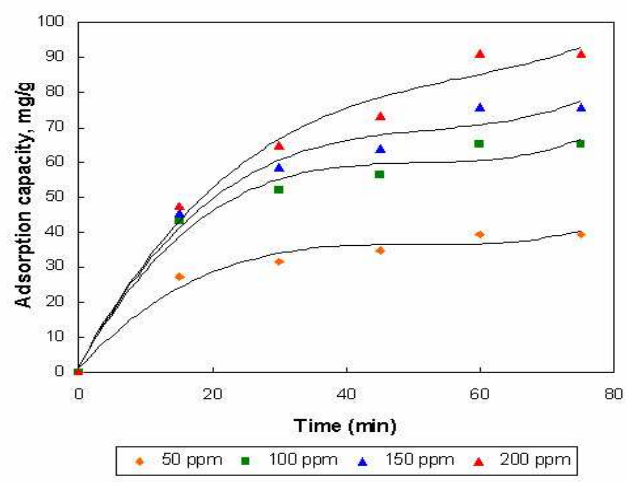

Figure 5. Effect of contact time on adsorption H-TS.

\section{Effect of dosage}

The effect of biosorbent dosage on the removal of chromium is shown Figure 7. The results indicate that the percent removal of chromium (VI) increases with increase in the amount of adsorbent and capable of removing for CTFS, H-TS and O-TS are $93 \%, 96 \%$ and $98 \%$ of $\mathrm{Cr}(\mathrm{VI})$ respectively. The removal of metal ions increased with the increase in biosorbent concentration and attained equilibrium after $0.25 \mathrm{~g}$ of adsorbent dosage for the chromium (VI) ions. This is due to availability of more biosorbent as well as greater availability of surface area (Aoyama, 2003). The removal of $\mathrm{Cr}(\mathrm{VI})$ is highly favoured at $\mathrm{pH} 3$ and the same $\mathrm{pH}$ is maintained through out the experiments.

\section{Adsorption isotherms}

Equilibrium data, commonly known as adsorption isotherms, are basic requirements for the design of adsorption systems. Classical adsorption models (Langmuir and Freundlich) are used to describe the equilibrium between adsorbed metal ions on the algal cell $\left(q_{e q}\right)$ and metal ions in solution $\left(C_{e q}\right)$ at a constant temperature. The equilibrium established between adsorbed component on the biosorbent and unadsorbed component in solution can be represented by adsorption isotherms. The most widely used isotherm equation for modeling equilibrium is the Langmuir equation which is valid for monolayer sorption onto a surface with a finite number of identical sites which are homogeneously distributed over the sorbent surface. The Freundlich expression is an empirical equation based on sorption on a heterogeneous surface suggesting that binding sites are not equivalent and/or independent. The linearized Freundlich and Langmuir adsorption isotherms of nickel (II) and copper (II) ions for both theforms of algae obtained at $33^{\circ} \mathrm{C}$ varying the concentration from 50$500 \mathrm{mg} / \mathrm{L}$ was shown in Figure 8 and Figure 9.

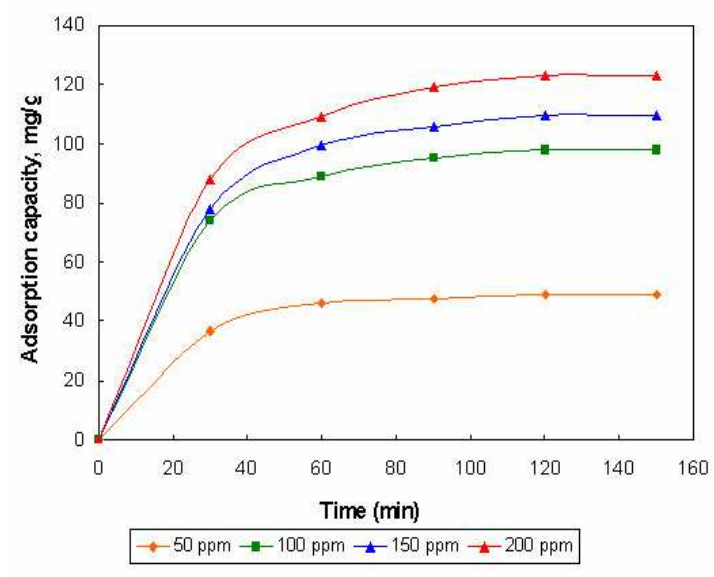

Figure 6. Effect of contact time on adsorption O-TS.

The linearized Langmuir and Freundlich models are used to describe adsorption of hexavalent $\mathrm{Cr}$ (VI) on crude and pretreated forms of the biosorbent.

The Langmuir isotherm takes the form,

$$
q_{e}=\frac{Q^{\circ} b C_{e}}{1+b C_{e}}
$$

where $Q^{o}$ is the maximum amount of the metal ion per unit weight of cell to form a complete monolayer on the surfaces at equilibrium concentrations and $b$ is related to affinity of the binding site. $Q^{o}$ and b are determined from the linear plots $1 / C_{e}$ vs. $1 / q_{e}$. Langmuir constants, $Q^{o}$ and $b$ and correlation factor $\left(\mathrm{r}^{2}\right)$ are presented in Table 4 and are shown in Figure 8. The values of $Q^{\circ}$ appear to be significantly higher for $\mathrm{Cr}(\mathrm{VI})$ on treated TS. The adsorption capacity of O-TS is higher than that of H-TS, which in turn is greater than that of CFTS. This may be due to the fact that oxalic acid has strong metal chetaling properties suggesting a ligand promoted mechanism, which 
Table 5. Adsorption capacities of different adsorbents for $\mathrm{Cr}(\mathrm{VI})$.

\begin{tabular}{|l|c|}
\hline \multicolumn{1}{|c|}{ Adsorbent } & $\mathbf{Q}^{\circ} \mathbf{~ ( m g / g )}$ \\
\hline Saw dust (Dikshit, 1989) & 16.05 \\
\hline Leaf mould (Sharma and Forster, 1994) & 43.00 \\
\hline Maize cob (Sharma and Forster, 1994) & 13.80 \\
\hline Palm pressed fibres (Tan et al. 1993) & 15.00 \\
\hline Pinnus sylvestris bark & 19.50 \\
(activated by 0.05 N NaCl) (Alves et al. 1993) & 86.20 \\
\hline O. anthropi (Ozdemir et al. 2003) & 74.62 \\
\hline CFTS (present work) & 140.84 \\
\hline H-TS (present work) & 151.51 \\
\hline PTS2 (present work) & \\
\hline
\end{tabular}

is the main mechanism of mineral dissolution (Fomina et al. 2005).

The empirical Freundlich equation is written as

$$
q_{b}=K_{F} C_{b}^{\frac{1}{n}}
$$

where $K_{F}$ and $n$ are Freundlich constants and are indicators of adsorption capacity and intensity respectively. The values of $K_{F}, n$ and correlation coefficients $\left(\mathrm{r}^{2}\right)$ are presented in Table 4 and are shown in Figure 9. In general, $n$ values are less than unity indicating that the surface of the adsorbent is heterogeneous in nature (Lyubchik et al. 2004). The differences in the Freundlich parameters for each biosorbent are probably related to their molecular structures. The results of equilibrium of biosorption of hexavalent chromium thus fit to the equations. Both models were developed for a single-layer adsorption. However, the Freundlich model physically provides a more realistic description of adsorption by organic matter because it accounts for different binding sites. But, in most cases, both equations fit the data set reasonably well for the experimental data over moderate ranges of concentration. Furthermore, the value of Freundlich exponent $n=0.90$ in the range of 3-5, indicates a favourable adsorption (Ho and McKay, 1998). Also, high adsorption capacity indicates the strong electrostatic force of attraction between dye molecules and biosorbent binding-sites (Kaewsarn and $\mathrm{Yu}$, 2001).

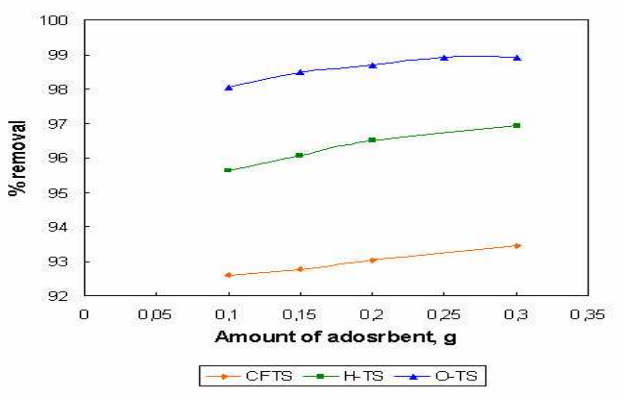

Figure 7. Effect of adsorbent dosage on $\mathrm{Cr}(\mathrm{VI})$ adsorption.
The extent of biosorption of chromium (VI) by tamarind shell and by different biosorbents is comparable with values found in literature and are presented in Table 5. The data in the table indicate that biosorbents CTFS, H-TS and O-TS have maximum adsorption capacity compared to many adsorbents.

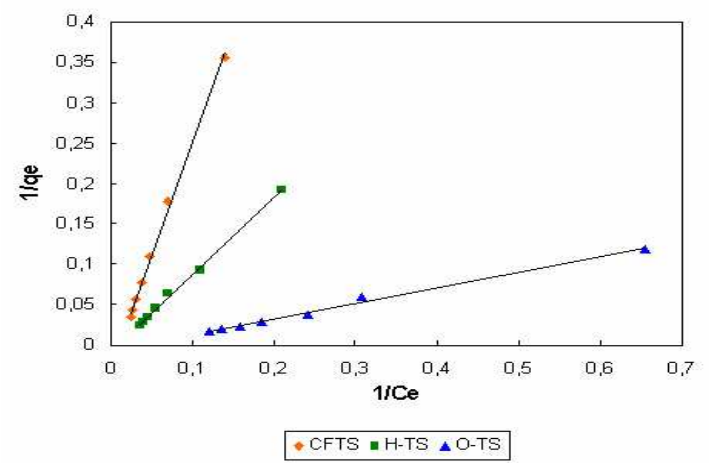

Figure 8. Langmuir isotherms for the adsorption of $\mathrm{Cr}(\mathrm{VI})$ on tamarind shell.

\section{CONCLUDING REMARKS}

The results obtained have shown that tamarind fruit shells both in its natural and acid treated forms are excellent biosorbents for the removal of chromium ions. The maximum uptake of chromium (VI) ions occurs at $\mathrm{pH} 3$. Increase in the amount of biosorbent increases the percent removal of the metal ions. Further, the biosorbents are characterized by porosimetry, EDXRF spectra and FTIR spectral analyses. The data fits well to both Langmuir and Freundlich isotherms and the monolayer maximum adsorption capacities of CTFS, H-TS and O-TS are 74.62 $\mathrm{mg} / \mathrm{g}, \quad 140.84 \mathrm{mg} / \mathrm{g}$, and $151.51 \mathrm{mg} / \mathrm{g}$ respectively. Therefore, the present study clearly demonstrates the possibility of usage of low cost biosorbent, tamarind fruit shells and pretreated tamarind fruit shells as suitable alternatives for the removal of chromium ions.

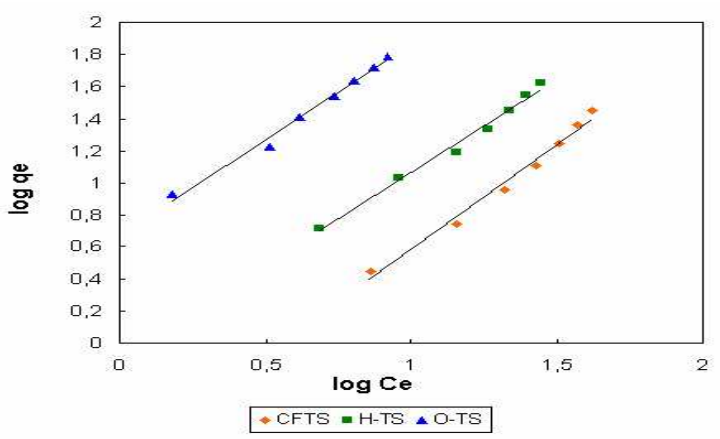

Figure 9. Freundlich isotherms for the adsorption of $\mathrm{Cr}(\mathrm{VI})$ on tamarind shell. 


\section{REFERENCES}

AGARWAL, G.S.; BHUPTAWAT, H.K. and CHAUDHARI, S. Biosorption of aqueous $\mathrm{Cr}(\mathrm{VI})$ by Tamarindus indica seeds. Bioresource Technology, May 2006, vol. 97, no. 7, p. 949-956.

ALVES, M.M.; GONZÁLEZ BEÇA, C.G.; GUEDES DE CARVALHO, R.; CASTANHEIRA, J.M.; SOL PEREIRA, M.C.; and VASCONCELOS, L.A.T. Chromium removal in tannery wastewaters "polishing" by Pinus sylvestris bark. Water Research, August 1993, vol. 27, no. 8, p. 1333-1338.

AOYAMA, Masakazu. Removal of Cr(VI) from aqueous solution by London plane leaves. Journal of Chemical Technology and Biotechnology, May 2003, vol. 78, no. 5, p. 601-604.

BODDU, Veera M.; ABBURI, Krishnaiah; TALBOTT, Jonathan L. and SMITH, Edgar D. Removal of hexavalent chromium from wastewater using a new composite chitosan biosorbent. Environmental Science and Technology, September 2003, vol. 37, no. 19, p. 4449-4456.

BROWN, P.A.; GILL, S.A. and ALLEN, S.J. Metal removal from wastewater using peat. Water Research, November 2000, vol. 34, no. 16, p. 3907-3916.

CABUK, Ahmet; ILHAN, Semra; FILIK, Cansu and CALISKAN, Figen. $\mathrm{Pb}^{2+}$ biosorption by pretreated fungal biomass. Turkish Journal of Biology, February 2005, vol. 29 , no. 1 , p. 23-28.

CHEUNG, W.H.; NG, J.C.Y. and MCKAY, G. Kinetic analysis of the sorption of copper (II) ions on chitosan. Journal of Chemical Technology and Biotechnology, May 2003, vol. 78, no. 5, p. 562-571.

DIKSHIT, V.P. Removal of chromium (VI) by adsorption using sawdust. National Academy of Science Letters, 1989, vol. 12 , no. 12 , p. 419-421.

DÖNMEZ, Gönül and AKSU, Zümriye. Removal of chromium (VI) from saline wastewaters by Dunaliella species. Process Biochemistry, December 2002, vol. 38, no. 5, p. 751-762.

FOMINA, M.; HILLIER, S.; CHARNOCK, J.M.; MELVILLE, K.; ALEXANDER, I.J. and GADD, G.M. Role of oxalic acid overexcretion in transformations of toxic metal minerals by beauveria caledonica. Applied and Environmental Microbiology, January 2005, vol. 71, no. 1, p. 371-381.

HO, Y.S. and MCKAY, G. Sorption of dye from aqueous solution by peat. Chemical Engineering Journal, June 1998, vol. 70, no. 2, p. 115-124.
HO, Y.S. and MCKAY, G. Sorption of lead (II) ions on peat. Water Research, February 1999, vol. 33, no. 2, p. 578584.

HO, Y.S. and MCKAY, G. The kinetics of sorption of divalent metal ions onto sphagnum moss peat. Water Research, February 2000, vol. 34, no. 3, p. 735-742.

HUANG, C. and HUANG, C.P. Application of Aspergillus Oryzae and Rhizopus Oryzae for $\mathrm{Cu}(\mathrm{II})$ removal. Water Research, September 1996, vol. 30, no. 9, p. 1985-1990.

KAEWSARN, Pairat and YU, Qiming. Cadmium (II) removal from aqueous solutions by pretreated biomass of marine algae Padina sp. Environmental Pollution, April 2001, vol. 112, no. 2, p. 209-213.

KLIMMRK, S.; STAN, H.J.; WILKE, A.; BUNKE, G. and BUCHHOLZ, R. Comparative analysis of the Biosorption of cadmium, lead, nickel and zinc by Algae. Environmental Science and Technology, October 2001, vol. 35, no. 21, p. 4283-4288.

KAWAMURA, Yoshihide; YOSHIDA, Hiroyuki; ASAI, Satoru and TANIBE, Hiroaki. Breakthrough curve for adsorption of mercury (II) on polyaminated highly porous chitosan beads. Water Science and Technology, 1997, vol. 35 , no. 7, p. $97-105$.

LASZLO, Joseph A. and DINTZIS, Frederick R. Crop resides as Ion exchange material. Treatment of soybean hull and sugar beet fiber (pulp) with epichlorohydrin to improve cation-exchange capacity and physical stability. Journal of Applied Polymer Science, April 1994, vol. 52, no. 4, p. 531538.

LYUBCHIK, Sergei I.; LYUBCHIK, Andrei I.; GALUSHKO, Olga L.; TIKHONOVA, Lilia P.; VITAL, Joaquim; FONSECA, Isabel M. and LYUBCHIK, Svetlana B. Kinetics and thermodynamics of the $\mathrm{Cr}(\mathrm{III})$ adsorption on the activated carbon from co-mingled wastes. Colloids and Surfaces A: Physicochemical and Engineering Aspect, August 2004, vol. 242, no. 1-3, p. 151-158.

MAHVI, Amir Hossein; NAGHIPOUR, Dariush; VAEZI, Forugh and NAZMARA, Shahrokh. Teawaste as an adsorbent for heavy metal removal from industrial wastewaters. American Journal of Applied Sciences, January 2005, vol. 2, no. 1, p. 372-375.

MARSHALL, W.E.; WARTELLE, L.H.; BOLER, D.E. and TOLES, C.A. Metal ion adsorption by soybean hulls modified with citric: a comparative study. Environmental Technology, June 2000, vol. 21, no. 6, p. 601-607.

MARATHE, R.M.; ANNAPURE, U.S.; SINGHAL, R.S. and KULKARNI, P.R. Gelling behaviour of polyose from 
tamarind seed kernel polysaccharide. Food Hydrocolloids, September 2002, vol. 16, no. 5, p. 423-426.

OZDEMIR, Guven; CEYHAN, Nur; OZTURK, Tansel; AKIRMAK, Feyza and COSAR, Tamer. Biosorption of chromium(VI), cadmium(II) and copper(II) by Pantoea sp. TEM18. Chemical Engineering Journal, September 2004, vol. 102 , no. 3 , p. 249-253.

OZDEMIR, Guven; OZTURK, Tansel; CEYHAN, Nur; ISLER, Rahim and COSAR, Tamer. Heavy metal biosorption by biomass of Ochrobactrum anthropi producing exopolysaccharide in activated sludge. Bioresource Technology, October 2003, vol. 90, no. 1, p. 71-74.

PRAKASHAM, R.S.; MERRIE, J.S.; SHEELA, R.; SASWATHI, N. and RAMAKRISHNA, S.V. Biosorption of chromium VI by free and immobilized Rhizopus arrhizus. Environmental Pollution, March 1999, vol. 104, no. 3, p. 421-427.

REDDAD, Zacaria; GERENTE, Claire; ANDRES, Yves and LE CLOIREC, Pierre. Adsorption of several metal ions onto a low cost biosorbent: Kinetic and Equilibrium studies. Environmental Science and Technology, March 2002, vol. 36, no. 9 , p. 2067-2073.

RICOU-HOEFFER, P.; LECUYER, I. and LE CLOIREC, P. Experimental design methodology applied to adsorption of metallic ions onto fly ash. Water Research, March 2001, vol. 35 , no. 4 , p. $965-976$.

ROUQUEROL, J.; AVNIR, D.; FAIRBRIDGE, C.W.; EVERETT, D.H.; HAYNES, J.H.; PERNICONE, N.; RAMSAY, J.D.F.; SING, K.S.W. and UNGER, K.K. Recommendations for the characterization of porous solids. Pure and Applied Chemistry, August 1994, vol. 66, no. 8, p. 1739-1758.

SHARMA, D.C. and FORSTER, C.F. A preliminary examination into the adsorption of hexavalent chromium using low-cost adsorbents. Bioresource Technology, 1994, vol. 47 , no. 3 , p. $257-264$.

SHEKINAAH, P.; KADIRVELU, K.; KANMANI, P.; SENTHILKUMAR, P. and SUBBURAM, V. Adsorption of lead(II) from aqueous solution by activated carbon prepared from Eichhornia. Journal of Chemical Technology and Biotechnology, April 2002, vol. 77, no. 4, p. 458-464.

TAN, W.T.; OOI, S.T. and LEE, C.K. Removal of chromium (VI) from solution by coconut husk and palm pressed fibres. Environmental Technology, March 1993, vol. 14 , no. 3 , p. $277-282$.

TEXIER, Anne-Claire; ANDRES, Yves and LE CLOIREC, Pierre. Selective biosorption of lanthanide ( $\mathrm{La}, \mathrm{Eu}, \mathrm{Yb}$ ) ions by Pseudomonas aeruginosa. Environmental Science and Technology, February 1999, vol. 33, no. 3, p. 489-495.

UDAYBHASKAR, P.; IYENGAR, L. and ABHAKAR RAO, A.V.S. Hexavalent chromium interaction with chitosan. Journal of Applied Polymer Science, February 1990, vol. 39, no. 3, p. 739-747.

VERMA, A.; CHAKRABORTY, S. and BASU, J.K. Adsorption study of hexavalent chromium using tamarind hull-based adsorbents. Separation and Purification Technology, July 2006, vol. 50, no. 3, p. 336-341.

VOLESKY, Bohumil. Biosorption of Heavy Metals. Boca Raton, FL, CRC Press, 1990. 408 p. ISBN 0-84-934917-6.

VOLESKY, Bohumil. Advances in biosorption of metals: selection of biomass types. FEMS Microbiology Reviews, August 1994, vol. 14, no. 4, p. 291-302.

WARTELLE, L.H. and MARSHALL, W.E. Citric acid modified agricultural by products as copper ion adsorbents. Advances in Environmental Research, June 2000, vol. 4, no. 1 , p. 1-7. 